\title{
Oral health behavior and its association with the Caries Index in visually impaired children
}

\author{
Mega Moeharyono Puteri \\ | Fadila Kemala Dwi Ramadhani Ruslan \\ Teguh Budi Wibowo
}

Department of Pediatric Dentistry, Faculty of Dental Medicine, Universitas Airlangga,

Surabaya, Indonesia

Correspondence

Mega Moeharyono Puteri, Department of

Pediatric Dentistry, Faculty of Dental

Medicine, Universitas Airlangga, Surabaya,

Indonesia.Email: mega-m-p@fkg.unair.ac.id

\begin{abstract}
Aim: To assess the correlation between oral health behavior and the Caries Index (CI) among visually impaired children.

Methods and Results: An analytical cross-sectional study was conducted from September to October 2017 in four schools in Surabaya, Indonesia. A total of 34 visually impaired and 34 nonvisually impaired children were selected and included in the study using a total sampling method. The oral health knowledge of, attitude towards, and practice of subjects were assessed by means of questionnaire. The author subsequently performed an intraoral examination of all subjects. The presence and extent of dental caries were recorded using $\mathrm{dmft}$ and DMFT scoring and categorized according to WHO classification. Visually impaired children were shown to have a low confidence of interval $[\mathrm{CI}]$ of 1.5. A Spearman's statistical test showed that, while knowledge significantly affected the CI of visually impaired children $(P<.05)$, attitude $(P=.98)$, or practice $(P=.42)$ did not.
\end{abstract}

Conclusion: A correlation clearly exists between oral health knowledge relating to CI in visually impaired children. However, there appeared to be no relationship between attitudes towards and actions in maintaining dental health through a CI in visually impaired children.

\section{K E Y W O R D S}

caries, oral health behavior, visually impaired children

\section{1 | INTRODUCTION}

Vision loss, also known as visual impairment, is a functional limitation that renders individuals unable to obtain information from their surroundings by means of their sight. ${ }^{1}$ According to the WHO (2010), approximately 285 million people suffer from this medical condition: 39 million people experienced total vision loss, while the remaining 246 million suffered impaired vision. Of these cases, 19 million cases affected children. ${ }^{2}$
Children with visual impairment demonstrate limited ability to perform everyday activities, one of them being an appropriate personal oral hygiene regime. ${ }^{3}$ This is due to the fact that it is more challenging for people with defective sight to gain access to dental care. ${ }^{4}$ Consequently, children with this disability run greater risk of developing dental caries due to the difficulties they experience in cleaning plaque and recognizing the early symptoms of tooth decay such as discoloration (white spots). ${ }^{5}$ 
Dental caries, a condition in which the localized tooth surface consisting of the enamel, dentin, and cementum is destroyed, is known to be caused by multiple risk factors including the host, agent (microorganisms), substrate, and time. Moreover, it is also widely accepted that the behavior, environment, and access to health care on the part of individuals all exacerbate the risk of developing caries. ${ }^{6,7}$

The dental and oral health of an individual can be indicative of their knowledge of, attitude towards, and practice in maintaining oral hygiene that can be classified into three types of behavior: health maintenance, seeking access to healthcare, and maintaining a salubrious environment. ${ }^{8}$

Despite the improving efforts of dental health professionals to enhance public oral health, according to Gokhale et al, the incidence of dental caries continues to increase. ${ }^{9}$ In a study conducted by John et al, the Caries Index (CI) of children with visual impairment in Chennai, India was high at $4.5 .{ }^{10}$ On the other hand, Reddy et al, reported a low CI of 1.1 in visually impaired children. In Medan, Indonesia, children with visual impairment was reported by Girsang to have an even higher CI of 5.5. ${ }^{11}$ Based on these studies, it remains debatable whether a correlation between quality of sight and CI exists. Therefore, further information regarding the association between these two variables is required. This research investigates the correlation between oral health behavior and CI in children with compromised vision.

\section{2 | METHODS}

This research employed an observational cross-sectional study method approved by the Ethical Research Committee of the Faculty of Dental Medicine, Universitas Airlangga (192/HRECC.FODM/IX/2017).

This research was conducted between September and October 2017 in four Surabaya-based schools: Sekolah Dasar Luar Biasa A (SDLB-A), Sekolah Menengah Pertama Luar Biasa A (SMPLB-A), Sekolah Dasar Negeri Pacarkeling IV, and Sekolah Menengah Pertama Negeri 29. A total sample of 68 subjects (34 visually impaired, 34 nonvisually impaired) constituted the research population. The inclusion criteria for members of the visually impaired group were as follows: children aged 6-16 years old presenting total vision loss who were willing and cooperative participants in the research. Meanwhile, children aged between 6 and 16 years with no vision loss who had agreed to participate in the research and proved cooperative were eligible for inclusion in the nonvisually impaired group. Informed consent was obtained from children's legal guardians for being included in the study.

Two primary forms of data, questionnaires and intraoral examination, were employed during the research. The questionnaire comprised three sections: knowledge of, attitude towards, and practice in maintaining oral hygiene
T A B L E 1 CI of visually impaired group and nonvisually

impaired group

\begin{tabular}{|clllll|}
\hline & $\begin{array}{l}\text { Age } \\
\text { (Year) }\end{array}$ & $\mathbf{N}$ & $\begin{array}{l}\text { CI score } \\
\text { (category) }\end{array}$ & $\begin{array}{l}\text { Mean CI } \\
\text { score } \\
\text { (category) }\end{array}$ & $\begin{array}{l}\text { Significant } \\
(\boldsymbol{P} \text {-value) }\end{array}$ \\
\hline $\begin{array}{c}\text { Visually } \\
\text { impaired }\end{array}$ & $6-12$ & 17 & 2 (Low) & 1.5 (Low) & .12 \\
\hline & $13-16$ & 17 & $\begin{array}{l}1.1 \text { (Very } \\
\text { low) }\end{array}$ & .71 \\
\hline $\begin{array}{c}\text { Nonvisually } \\
\text { impaired }\end{array}$ & $6-16$ & 34 & - & 1.7 (Low) & - \\
\hline
\end{tabular}

(see Appendix) and had previously been tested for validity (Pearson significant values for all items $<0.05$ ) and reliability (Cronbach's Alpha $=0.705) .{ }^{12}$ The questionnaire was completed by interviewing the subject to elicit his/her knowledge, attitudes and practice regarding oral hygiene. A score of 1 was assigned to every correct answer, while 0 was assigned to ones which were incorrect. Those who scored higher than 4.6 on the "knowledge" and "attitude" categories were classified as high/good, while a score of $<4.6$ was deemed to be low. Meanwhile, in the "oral hygiene practice" section, a score of $>5.4$ was classified as good and $<5.4$ as poor.

Intraoral examinations, performed on the subjects using a dental mirror and sterile probe, were undertaken to assess the severity of dental caries, the results of which were recorded in a CI form. The computed results were classified in terms of severity according to $\mathrm{WHO}$ categories: very low $(\mathrm{CI}<1.2)$, low (CI: 1.2-2.6), moderate (2.7-4.4), high (4.5-6.5), and very high $(>6.5)$.

A 21 st version SPSS was used to analyze the data collected by means of both questionnaires and intraoral examinations. A $P$-value of $<.05$ was considered statistically significant.

\section{3 | RESULTS}

The mean CI of the visually impaired group members can be seen to be low at 1.5 and observed to be lower among its older members, as shown in Table 1. A low incidence of dental caries $(\mathrm{CI}=2.0)$ was reported among subjects in the 612 years age group $(n=17)$, while the remaining 17 subjects in the 13-16 years age group possessed a CI of 1.1 indicating very low severity. A Mann-Whitney test found the difference in CI between the two age groups to be statistically insignificant $(P$-value $=.12)$.

The nonvisually impaired group was observed to have low $\mathrm{CI}$ at 1.7. A Mann-Whitney test found that the difference in CI between visually impaired and nonvisually impaired groups was not statistically significant $(P$-value $=.71)$. Therefore, there was no difference in CI between the two groups.

A summary of the knowledge of, attitude towards, and practice in maintaining the oral health of visually impaired 
T A B L E 2 Correlation between knowledge of, attitude towards, and practice in maintaining dental and oral health as indicated by the CI of visually impaired group members

\begin{tabular}{|c|c|c|c|c|c|c|}
\hline \multirow[b]{3}{*}{ Category } & \multicolumn{6}{|l|}{ Domain } \\
\hline & \multicolumn{2}{|l|}{ Knowledge } & \multicolumn{2}{|l|}{ Attitude } & \multicolumn{2}{|l|}{ Practice } \\
\hline & High/good & Low/poor & High/good & Low/poor & High/good & Low/poor \\
\hline & $28(82.4 \%)$ & $6(17.6 \%)$ & $23(67.6 \%)$ & $11(32.4 \%)$ & $20(58.8 \%)$ & $14(41.2 \%)$ \\
\hline & \multicolumn{6}{|c|}{ Spearman's Rank Test ( $P$-value) } \\
\hline
\end{tabular}

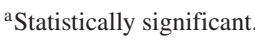

subjects is reported in Table 2. Of the 34 visually impaired subjects, $82.4 \%(n=28)$ possessed considerable knowledge regarding dental and oral health, while that of the remaining $17.6 \%$ was considered poor. A total of 23 subjects (67.6\%) possessed a positive attitude toward dental and oral health. Finally, the practice in maintaining oral health was good in $58.8 \%$ of the subjects $(n=20)$.

The relationship between the three domains, such as knowledge of, attitude towards, and practice in maintaining oral health and $\mathrm{CI}$ in visually impaired subjects was analyzed using a Spearman's Rank Test. The correlation between knowledge of oral and dental health and CI was statistically significant $(P$-value $<.05)$. The association between attitude towards and practice in maintaining oral health and $\mathrm{CI}$ were shown to be statistically insignificant ( $P$-value $=.98$ and .42 , respectively $)$.

\section{4 | DISCUSSION}

In this study, the dental CIs among visually impaired children were reported to be of low severity, a finding matching that of a study conducted by Reddy et al in which a low category CI was recorded in visually impaired children. ${ }^{13}$ This study also found a decrease in CI within older age groups, although the relationship was not statistically significant mirroring the findings of Kiswaluyo that a decline in CI was observable in older individuals due to the fact that they demonstrate greater awareness of dental and oral health care. ${ }^{14}$ Despite this, a study published by Singh et al concluded that no significant difference in CI existed in individuals between the ages of 9 and 15 because of their capacity to memorize, synthesize, and apply the information retrieved being equal. ${ }^{15}$

This comparison of CI in visually impaired and nonvisually impaired children showed no statistically significant difference, a result confirming that of a study by Herwis et al. Since the two groups demonstrated similar habits with regard to maintaining oral health, such as the level of sugar consumption and frequency of brushing, no significant difference in CI between groups was observed. ${ }^{16}$

A total of $82.4 \%$ of visually impaired subjects possessed good knowledge regarding dental and oral health maintenance. This was possibly due to their subjects having been formally educated in special needs schools under the management of Yayasan Pendidikan Anak Buta (YPAB) Surabaya, which received health advice from the community health clinics (Puskesmas). Moreover, nowadays, information about dental and oral health is easily accessible (eg, via television or advice from dental health professionals). ${ }^{17}$

A total of $67.6 \%$ of the participating visually impaired subjects demonstrated a positive attitude toward maintaining dental and oral health. The article written by Notoatmodjo argued that the cognitive ability of an individual can influence his/her attitude. Those aware of the importance and means of maintaining dental and oral hygiene are more likely to take appropriate action. ${ }^{8}$

Of the visually impaired group members, $58.8 \%$ followed good practice in maintaining oral health. According to Notoatmodjo, this is easier for an individual when access to a dentist, dental nurse, and healthcare facilities is available. ${ }^{8}$

The correlation between the knowledge that a subject possesses regarding the maintenance of oral health and CI is statistically significant. This finding matches that of the study by Marimbun et al, which posited the existence of a significant relationship between knowledge of oral health and $\mathrm{CI}$ in visually impaired subjects. A satisfactory understanding of dental and oral health would positively influence the attitude and actions of an individual with regard to oral health maintenance. Appropriate knowledge of dental and oral cleansing procedures represents the basis for maintaining oral hygiene. ${ }^{18}$

The attitude towards and practice of maintaining dental health were shown not to have a significant relationship with the CI. A study in 2009 also reported to have found no significant correlation between attitude and the dental CI. ${ }^{19}$ In keeping with the results contained in this article, Ahmad et al found that there was no causal link between oral hygiene maintenance and the severity of dental caries. ${ }^{20}$ The absence of these relationships may be attributable to the presence of enabling factors.

Enabling factors, for instance, parenting practice and access to healthcare facilities, could influence the attitude of an individual. The majority of visually impaired children 
studying at YPAB were observed to be very dependent on their parents or caregivers in performing daily activities. In addition to the three domains focused on in this study, deficient motor skills can also contribute to difficulties in maintaining dental health. ${ }^{21}$ Therefore, children who are visually impaired require the support of others. Parents or caregivers play a vital role in promoting children's dental and oral health such as motivating and assisting them to follow effective oral and dental hygiene practices and ensuring that they attend regular dental health check-ups. A good CI and effective dental care practice could be the result of accessible healthcare facilities such as a Puskesmas. According to Kencana , health education or counseling could positively influence the behavior of an individual including that relating to oral health. ${ }^{22}$

Based on the result of the study, a firm conclusion regarding the relationship between knowledge of oral health and the dental CI of visually impaired children can be drawn. However, there appeared to be no relationship between attitudes towards and actions in maintaining dental health through a CI in visually impaired children.

The limitation of this study includes the inability to investigate enabling and reinforcing factors contributing to CI. Although CI is advantageous in giving a broad view of caries experience of the subjects, it is less useful in estimating treatment needs, as the index gives equal weight to missing, untreated decayed, and well-restored teeth.

It is expected that visually impaired children can have good CI due to the community-based or group activities oral health promotion. Further studies should include a large group of visually impaired children and focus on the enabling factors and reinforcing factors, as these factors seem to give greater contribution in preventing caries, and become the key for caries prevention in visually impaired children.

\section{CONFLICT OF INTEREST}

The authors have declared that no competing interests exist.

\section{ETHICS STATEMENT}

This research has been approved by Research Ethical Committee of Faculty of Dental Medicine, Universitas Airlangga (No: 192/HRECC.FODM/IX/2017). Informed consent was obtained from all children's legal guardians for being included in the study.

\section{ORCID}

\author{
Mega Moeharyono Puteri \\ https://orcid.org/0000-0001-5551-4605
}

\section{R E F E R E N CES}

1. Permana H, Indahyani D, Yustisia Y. Kelarutan kalsium email pada saliva penderita tunanetra. Dentofasial. 2014;13(3):150-154.

2. World Oral Health Organization [homepage on the internet]. Visual impairment and blindness, 2014. http://www.who.int/blindness/en/. Accessed January 1, 2017.

3. Prashanth S, Bhatnagar S, Das UM, Gopu H. Oral health knowledge, practice, oral hygiene status, and dental caries prevalence among visually-impaired children in Bangalore. J Indian Soc Pedod Prev Dent. 2011;29(2):102-105.

4. Ozdemir-Ozenen D, Sungurtekin E, Cildir S, Sandali N. A comparison of the oral health status of children who are blind and children who are sighted in Istanbul. JVIB. 2012;106(6):362-367.

5. Samnieng P, Seehaumpai P, Wichachai S, Yosookh P. Oral health status and treatment need of visual impairment in Phitsanuloke, Thailand. JDI. 2014;21(2):63-67.

6. Mariati N. Pencegahan dan perawatan karies rampan. Biomedik. 2015;7(1):23-28.

7. Miftakhun N, Salinkun SunarjoL, Mardiati E. Faktor eksternal penyebab terjadinya karies gigi pada anak pra sekolah di PAUD Strowberry RW 03 kelurahan Bangetayu Wetan kota Semarang tahun 2016. Kesehatan Gigi. 2016;3(2):27-34.

8. Notoatmodjo S. Ilmu Perilaku Kesehatan. PT. Rineka Cipta, Indonesia: Edisi Revisi. Jakarta; 2010:20-32.

9. Gokhale N, Sivakumar N, Svsg N, Abinash M. Dental caries and body mass index in children of Nellore. J Orofac Sci. 2010;2(2):46.

10. John J, Daniel B, Paneerselvam D, Rajendran G. Prevalence dental caries, oral hygiene knowledge, status, and practices among visually-impaired individuals in Chennai, Tamil Nadu. Int J Dent. 2017;2017(9419648):1-6.

11. Girsang EN. Perbandingan Oral Hygiene Dan Karies Gigi Pada Anak Tunanetra Dan Tidak Tunanetra Usia 12 dan 15 Tahun di Medan. Medan, Indonesia: Universitas Sumatera Utara; 2003:27.

12. Suharsimi A. Manajemen Penelitian. PT. Rineka, Indonesia: Edisi revisi 6. Jakarta; 2009:14.

13. Reddy K, Sharma A. Prevalence of oral health status in visuallyimpaired children. J Indian Soc Pedod Prev Dent. 2011;29(1):1517.

14. Kiswaluyo. Hubungan usia dan jenis kelamin dengan kejadian karies gigi siswa sekolah dasar Sumbersari dan Puger kabupaten Jember. Prodenta. 2013;1(2):47-54.

15. Singh A, Dhawan P, Gaurav V, Rastogi P, Singh S. Assessment of oral health-related quality of life in 9-15 year old children with visual impairment in Uttarakhand, India. Dent Res J. 2017;14(1):43-49.

16. Herwis K, Ali A, Elturki Khamis. Oral health status of visuallyimpaired and sighted groups of children in Benghazi: a comparative study. LDJ. 2013;3:1-5.

17. Sharda AJ, Shetty S. Relationship of peridontal status and dental caries with oral health knowledge, attitude, and behaviour among professional students in India. Int J Oral Sci. 2009;1(4):196-206.

18. Marimbun BE, Mintjelungan CN, Pangemanan DHC. Hubungan tingkat pengetahuan tentang kesehatan gigi dan mulut dengan status karies gigi pada penyandang tunanetra. $e$-GiGi. 2016;4(2):177-182.

19. Linda Warni. Hubungan Perilaku Murid SD Kelas V dan VI Pada Kesehatan Gigi dan Mulut Terhadap Status Karies Gigi di Wilayah Kecamatan Delitua Kabupaten Deli Serdang. Medan, Indonesia: Thesis Universitas Sumatera Utara; 2009:20-25. 
20. Ahmad MS, Jindal MK, Khain S, Hshmi H. Oral health knowledge, practice, oral hygiene status and dental caries prevalence among visually-impaired students in residential institute of Aligarh. J Dent Oral Hyg. 2009; 1(2):22-26.

21. Suresan V, Das D, Jnaneswar A, Jha K, Kumar G, Subramaniam GB. Assessment of dental caries, oral hygiene status, traumatic dental injuries and provision of basic oral health care among visuallyimpaired children of Eastern Odisha. J Indian Soc Pedod Prev Dent. 2017;35(4):284-290.

22. Kencana IGS. Peranan perawat gigi dalam pemeliharaan kesehatan gigi dan mulut pada anak berkebutuhan khusus (disabled children). Kesehatan Gigi. 2014;2(2):260-265.

\section{SUPPORTING INFORMATION}

Additional supporting information may be found online in the Supporting Information section at the end of the article.

How to cite this article: Puteri MM, Ruslan FKDR, Wibowo TB. Oral health behavior and its association with the caries index in visually impaired children. Spec Care Dentist. 2019;1-5. https://doi.org/ $10.1111 / \mathrm{scd} .12439$ 